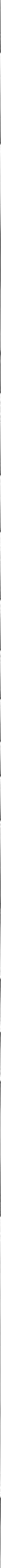




\section{Now is the Time}

Founded in 1991, TESCAN is becoming an industry leader by designing quality products, creating innovative solutions, and listening to our customers' needs.

-Thermionic Scanning Electron Microscopes

- Field Emission Scanning Electron Microscopes

- FIB-SEM Workstations

- Raman Correlative Microscopy

- Mineral Analysis Solutions

-ToF-SIMS

\section{Quality. Reliability. Performance. www.tescan-usa.com}

TESCAN USA Inc.

765 Commonwealth $\mathrm{Dr}$.

Suite 101

Warrendale, PA 15086

Ph: 724-772-7433

Fx: 724-772-7434 


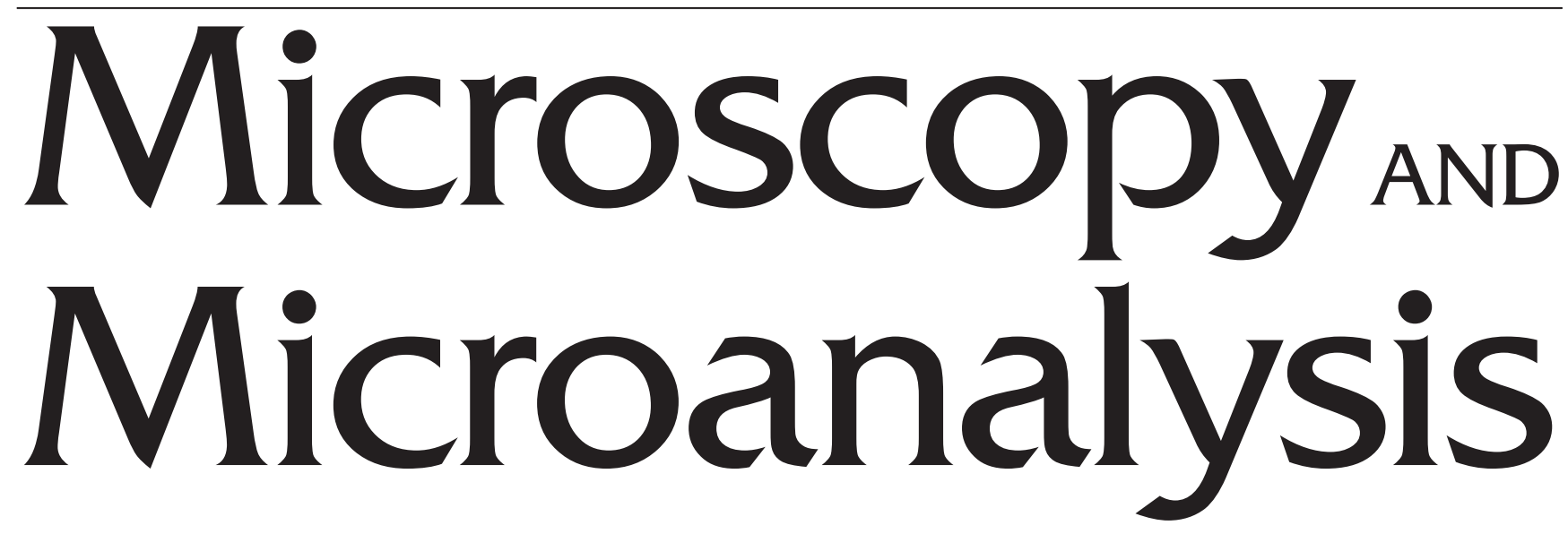

\section{An International Journal for the Biological and Physical Sciences}

THE OFFICIAL JOURNAL OF

MICROSCOPY SOCIETY OF AMERICA

MICROANALYSIS SOCIETY

MICROSCOPICAL SOCIETY OF CANADA /

SOCIÉTÉ DE MICROSCOPIE DU CANADA

MEXICAN MICROSCOPY SOCIETY

BRAZILIAN SOCIETY FOR MICROSCOPY AND MICROANALYSIS

VENEZUELAN SOCIETY OF ELECTRON MICROSCOPY

EUROPEAN MICROBEAM ANALYSIS SOCIETY

AUSTRALIAN MICROSCOPY AND MICROANALYSIS SOCIETY

PORTUGUESE SOCIETY FOR MICROSCOPY

\section{ROYAL MICROSCOPICAL SOCIETY}

GERMAN SOCIETY FOR ELECTRON MICROSCOPY

BELGIAN SOCIETY FOR MICROSCOPY

MICROSCOPY SOCIETY OF SOUTHERN AFRICA

Editor, Biological Applications

William A. Russin

Biological Imaging Facility

Department of Neurobiology

Northwestern University

Evanston, IL 60208

e-mail:w-russin@northwestern.edu

Editor, Biological Applications

Heide Schatten

Veterinary Pathobiology

University of Missouri-Columbia

Columbia, Missouri 65211-5030

e-mail: schattenh@missouri.edu

Center for Nanoscale Systems

Harvard University

Cambridge, MA 02138

e-mail: dcb@seas.harvard.edu

Editor, Scanning Probe

Microscopies

Andrew Magyar

Center for Nanoscale Systems

Harvard University

Cambridge, MA 02138

e-mail: amagyar@cns.fas.harvard.edu

Editor, Atom Probe

Thomas Kelly

Cameca Instruments, Inc.

A Business Unit of AMETEK, Inc.

Madison, WI 53711-4951

e-mail: Thomas.Kelly@ametek.com

e-mail: v-dravid@northwestern.edu
Editor, Microanalysis

John Mansfield

Electron Microbeam Analysis Lab

North Campus, 417 SRB

University of Michigan

Ann Arbor, MI 48109-2143

e-mail: jfmjfm@umich.edu

Editor, Correlative and Emerging Microscopy Applications

Vinayak P. Dravid

Materials Science and Engineering

Northwestern University

Evanston, Illinois 60208-3105

Editor, Plant Biology Applications

Rosemary White

CSIRO Plant Industry

Canberra, ACT 2601, Australia

e-mail: rosemary.white@csiro.au
Special Issues and Reviews Editor

Jay Jerome

Vanderbilt University Medical Center

Nashville, TN 37232

e-mail: jay.jerome@vanderbilt.edu

Book Review Editor

Cynthia S. Goldsmith

Centers for Disease Control

Atlanta, GA 30333

e-mail: csg1@cdc.gov

M\&M Program Guide Editor

Richard E. Edelmann

Miami University

Oxford, OH 45056

e-mail: edelmare@muohio.edu

Proceedings Editor

Gail Celio

University of Minnesota

St. Paul, MN 55108

e-mail: celio001@umn.edu

Administrative Editor

John Shields

University of Georgia

Athens, GA 30602

e-mail: jpshield@uga.edu 


\section{Editorial Board}

$\begin{array}{ll}\text { Ralph Albrecht } & \text { University of Wisconsin, Madison, Wisconsin } \\ \text { Ilke Arslan } & \text { Pacific Northwest Laboratory, Richland, Washington } \\ \text { Grace Burke } & \text { University of Manchester, Manchester, England } \\ \text { Barry Carter } & \text { University of Connecticut, Storrs, Connecticut } \\ \text { Wah Chiu } & \text { Baylor College of Medicine, Houston, Texas } \\ \text { Niels de Jonge } & \text { INM Institute for New Materials, Saarbrücken, Germany } \\ \text { Alberto Diaspro } & \text { University of Genoa, Italy } \\ \text { Elizabeth Dickey } & \text { North Carolina State University, Raleigh } \\ \text { Mark Ellisman } & \text { University of California at San Diego, San Diego, California } \\ \text { Pratibha Gai } & \text { University of York, United Kingdom } \\ \text { Marija Gajdardziska-Josifovska } & \text { University of Wisconsin-Milwaukee, Milwaukee, Wisconsin } \\ \text { Dale Johnson } & \text { University of South Florida, Tampa, Florida } \\ \text { Paul Kotula } & \text { Sandia National Labs, Albuquerque, New Mexico } \\ \text { William Landis } & \text { University of Akron, Akron, Ohio } \\ \text { Eric Lifshin } & \text { SUNY at Albany, Albany, New York } \\ \text { Charles Lyman } & \text { Lehigh University, Bethlehem, Pennsylvania } \\ \text { Dale Newbury } & \text { National Institute of Standards and Technology, Gaithersburg, Maryland } \\ \text { Jean-Paul Revel } & \text { California Institute of Technology, Pasadena, California } \\ \text { David Smith } & \text { Arizona State University, Tempe, Arizona } \\ \text { Nan Yao } & \text { Princeton University, Princeton, New Jersey } \\ \text { Nestor Zaluzec } & \text { Argonne National Laboratory, Argonne, Illinois } \\ & \end{array}$

\section{Editorial Board Representatives from Affiliated Societies}

Masashi Watanabe

Gautam Kumar Dey

Gema Gonzalez

Michael Robertson

Brendan Griffin

Guillermo Solorzano

Mike Matthews

Miguel Yacaman

Henrique Almeida

\section{Founding Editor}

Jean-Paul Revel
Lehigh University (MAS)

Bhabha Atomic Research Centre (EMSI)

Venezuelan Institute for Scientific Investigation (Venezuela)

Acadia University, Wolfville, Nova Scotia (Canada)

University of Western Australia (AMMS)

Pontificia Universidade Catolica, Rio de Janeiro (Brazil)

Atomic Weapons Establishment, Reading, Great Britain (EMAS)

Mexico Institute for Nuclear Research (Mexico)

Universidade do Porto (Portugal)

California Institute of Technology, Pasadena, California

\section{Previous Editors-in-Chief}

Dale Johnson

Charles Lyman
University of South Florida, Tampa, Florida

Lehigh University, Bethlehem, Pennsylvania

This journal is part of the Cambridge Journals Online service. Access to online tables of contents and article abstracts is available to all researchers at no cost. Access to full-text articles online is provided to those with online subscription. Online subscriptions must be activated. Once your subscription is activated, free access to past, present, and forthcoming articles is available at:

\section{Microscopy and Microanalysis website: journals.cambridge.org/MAM.}

Instructions for authors submitting manuscripts may be found at journals.cambridge.org/MAM. Select "Further Information" then select "Instructions for Contributors." An abbreviated version of these instructions will be published in the first issue (February) of each volume. 


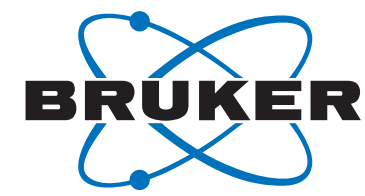

\section{Techniques - 1 Workflow.}

\section{ESPRIT 2, the only software which combines 4 microanalysis methods.}
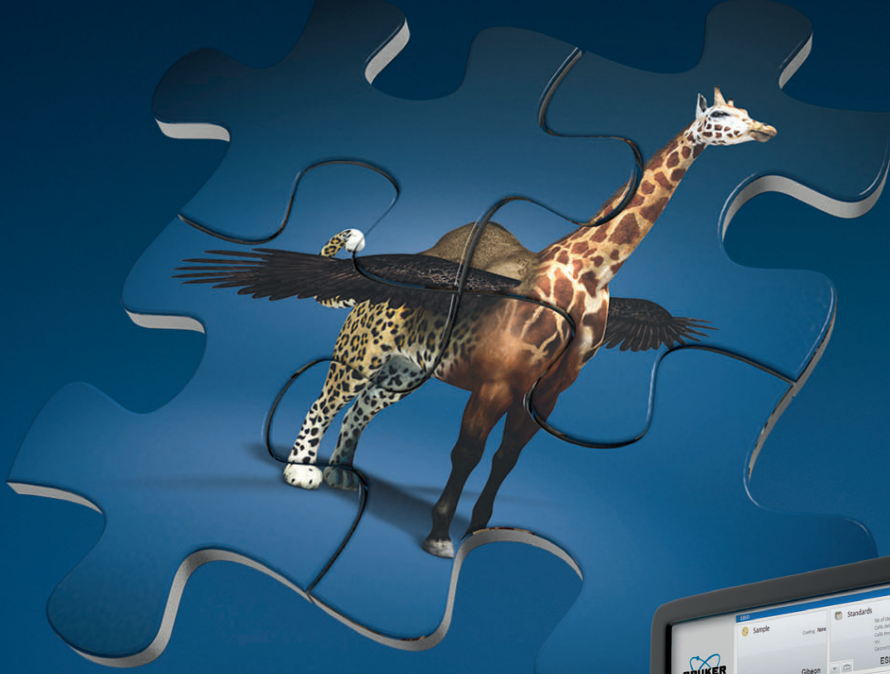

- Comprehensive management of analysis and results from EDS, WDS, EBSD and Micro-XRF with one software

- Complementary techniques provide you the most accurate and reliable results

- Zeta factor quantification for characterization of thin layers

Someone has to be first.

\section{口}

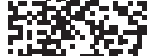

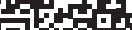

arpitit

Innovation with Integrity 


\section{Microscopy AND Microanalysis}

Microscopy and Microanalysis publishes original research papers dealing with a broad range of topics in microscopy and microanalysis. These include articles describing new techniques or instrumentation and their applications, as well as papers in which established methods of microscopy or microanalysis are applied to important problems in the fields of biology or materials science. Microscopy and microanalysis are defined here in a broad sense, and include all current and developing approaches to the imaging and analysis of microstructure. The criteria for acceptance of manuscripts are the originality and significance of the research, the quality of the microscopy or microanalysis involved, and the interest for our readership.

Four types of communications are published in the Journal. Regular Articles are of substantial length and describe the findings of an original research project that satisfies the aims and scope of the Journal, described above. Review Articles summarize the current status of an important area within the aims and scope of the Journal. Letters to the Editor usually contain comments on recent articles that have appeared in the Journal. Book Reviews are also published, but these are solicited only through the Book Review Editor.

\section{Instructions for Contributors}

Instructions for authors contributing manuscripts may be found at http://mc.manuscriptcentral.com/mam under "Resources: Instructions and Forms." Authors may also visit http://www.journals.cambridge.org/ jid_MAM, select "Further Information," and then select "Instructions for Contributors." An abbreviated version of these instructions will be published in the first issue (February) of each volume.

\section{Copyright Information}

Submission of a manuscript implies: that the work described has not been published before (except in the form of an abstract or as part of a published lecture, review, or thesis); that it is not under consideration for publication elsewhere; that its publication has been approved by all coauthors, if any, as well as by the responsible authorities at the institute where the work has been carried out; that, if and when the manuscript is accepted for publication, the authors agree to automatic transfer of the copyright to the Microscopy Society of America; that the manuscript will not be published elsewhere in any language without the consent of the copyright holders; and that written permission of the copyright holder is obtained by the authors for material used from other copyrighted sources.

All articles published in this journal are protected by copyright, which covers the exclusive rights to reproduce and distribute the article (e.g., as offprints), as well as all translation rights. No material published in this journal may be reproduced photographically or stored on microfilm, in electronic data bases, video disks, etc., without first obtaining written permission from the publisher.

The use of general descriptive names, trade names, trademarks, etc., in this publication, even if not specifically identified, does not imply that these names lack protection by the relevant laws and regulation.

Authorization to photocopy items for internal or personal use, or the internal or personal use of specific clients, is granted by Cambridge University Press, provided that the appropriate fee is paid directly to Copyright Clearance Center, 222 Rosewood Drive, Danvers, MA 01923, USA (Tel: (508) 750-8400), stating the ISSN (1431-9276), the volume, and the first and last page numbers of each article copied. The copyright owner's consent does not include copying for general distribution, promotion, new works, or resale. In these cases, specific written permission must first be obtained from the publisher.

\section{Disclaimer}

The Microscopy Society of America, the other societies stated, and Cambridge University Press cannot be held responsible for errors or for any consequences arising from the use of the information contained in this journal. The appearance of scientific reports and/or workshops, or any other material in Microscopy and Microanalysis does not constitute an endorsement or approval by The Microscopy Society of America of the findings, data, conclusions, recommendations, procedures, results, or any other aspect of the content of such articles. The appearance of advertising in Microscopy and Microanalysis does not
Aims and Scope

constitute an endorsement or approval by The Microscopy Society of America of the quality or value of the products advertised or any of the claims, data, conclusions, recommendations, procedures, results, or any other information included in the advertisements.

While the advice and information in this journal is believed to be true and accurate at the date of its going to press, neither the authors, the editors, nor the publisher can accept any legal responsibility for any errors or omissions that may be made.

\section{Subscription Information}

Microscopy and Microanalysis is published bimonthly in February, April, June, August, October, and December by Cambridge University Press. Three supplements (Meeting Guide, Program Guide, and Proceedings) are published in June and August.

Society Rates: Members of the Microscopy Society of America should contact the MSA Business Office for all subscription inquiries: Microscopy Society of America, Hachero Hill, Inc., 11260 Roger Bacon Drive, Suite 402, Reston, VA 20190, Tel.: (703) 964-1240, Ext. 14, E-mail: nicoleguy@mindspring.com, URL: www.msa.microscopy.org. Members of other affiliated societies should contact their respective society business offices for all subscription inquiries.

Subscription Rates: Institutions print and electronic: US \$1705.00 in the USA, Canada, and Mexico; UK $£ 1025.00+$ VAT elsewhere. Institutions online only: US \$1264.00 in the USA, Canada, and Mexico; UK

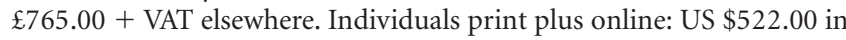

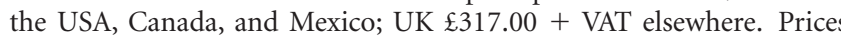
include postage and insurance.

USA, Canada, and Mexico: Subscribers in the USA, Canada, and Mexico should send their orders, with payment in US dollars or the equivalent value in Canadian dollars, to: Cambridge University Press, Customer Services Department (Journals), 100 Brook Hill Drive, West Nyack, NY 10994-2133, USA. Tel: (845) 353-7500. Fax: (845) 353-4141. Orders may be phoned direct (toll free): (800) 872-7423. E-mail: journals_subscriptions@cup.org.

Outside North America: Subscribers elsewhere should send their orders, with payment in sterling, to: Customer Services Department (Journals), Cambridge University Press, The Edinburgh Building, Shaftesbury Road, Cambridge, CB2 8RU, UK. Tel: +44 (0)1223 326070. Fax: +44 (0)1223 325150. E-mail: journals@cambridge.org

Change of address: Allow six weeks for all changes to become effective. All communications should include both old and new addresses (with postal codes) and should be accompanied by a mailing label from a recent issue. Society members should contact their respective society business offices to inform them of address changes.

\section{Editorial Office}

Robert L. Price, Editor in Chief, Department of Cell and Developmental Biology and Anatomy, School of Medicine, University of South Carolina, 6439 Garner's Ferry Road, Bldg. 1 B-60, Columbia, SC 29209, USA; Tel: (803) 216-3824; Fax: (803) 733-3212; E-mail: Bob.Price@uscmed.sc.edu.

\section{Office of Publication}

Cambridge University Press, 32 Avenue of the Americas, New York, NY 10013-2473, USA; Tel: (212) 337-5000; Fax: (212) 337-5959.

\section{Advertising Sales \& Production}

Kelly Miller, M.J. Mrvica Associates, Inc., 2 West Taunton Avenue, Berlin, NJ 08009, USA; Tel: (856) 768-9360; Fax: (856) 753-0064.

(C) 2015 by Microscopy Society of America. Printed in the United States on acid-free paper. Periodicals postage paid at New York, NY, and additional mailing offices. Return postage guaranteed. Postmaster: Send address changes in the U.S.A. and Canada to Microscopy and Microanalysis, Subscription Department, Cambridge University Press, 100 Brook Hill Drive, West Nyack, NY 10994-2133. 


\section{Your FIB-SEM for High Throughput Nanotomography and Nanofabrication ZEISS Crossbeam 340 and 540}
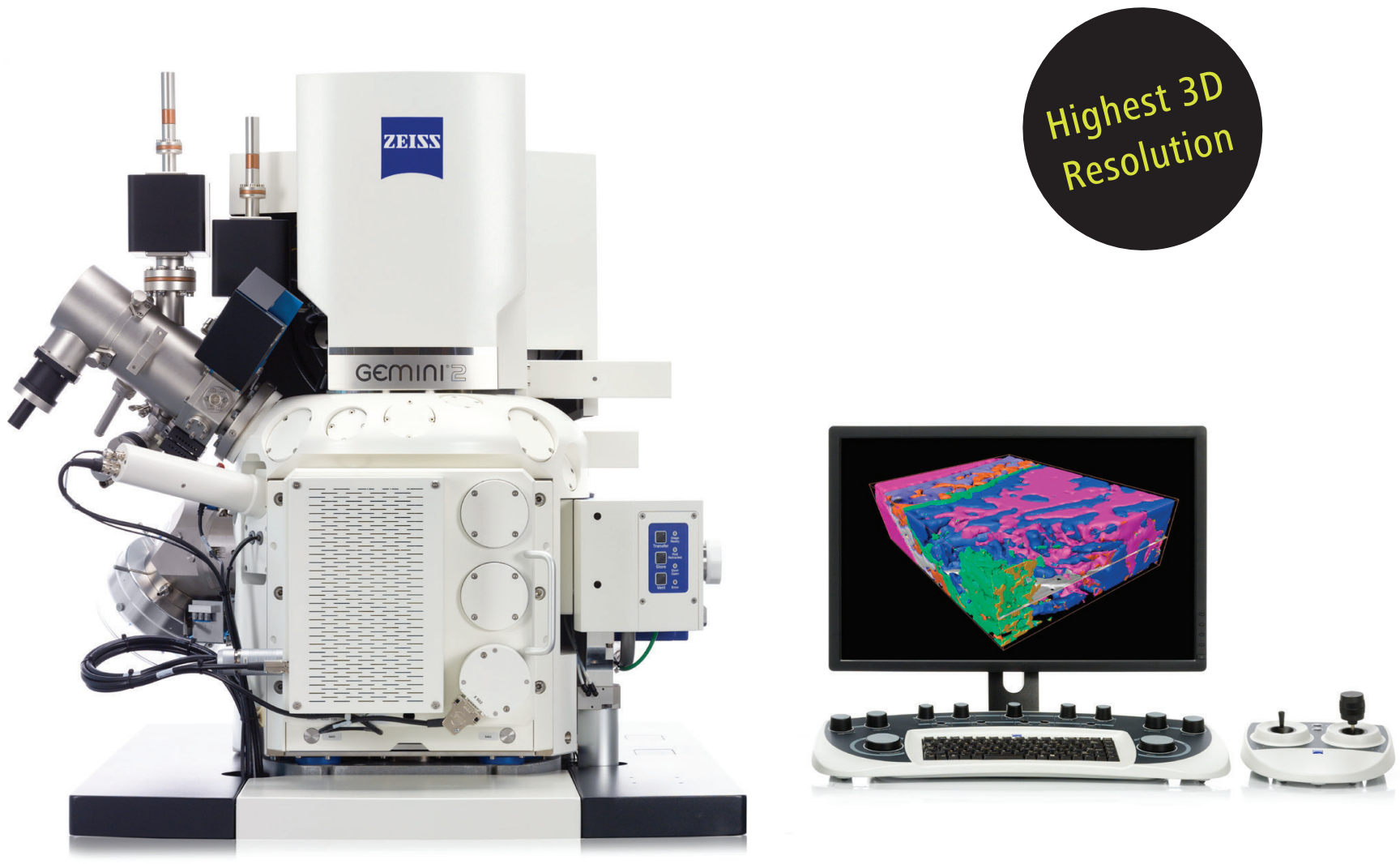

Enjoy High Productivity with an Open 3D Nano-Workstation

With ZEISS Crossbeam 340/540 you experience an outstanding combination of imaging performance and analytical power. Process and prepare any sample on a nanoscopic scale with the nextgeneration FIB. Observe your process in parallel with the superb optics of the GEMINI column. Enjoy demanding experiments with your Crossbeam especially designed for long-term stability. Find out more and book a hands-on demonstration in one of our ZEISS Microscopy Labs now.

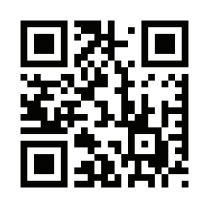

www.zeiss.com/crossbeam

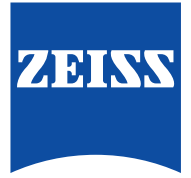

We make it visible. 

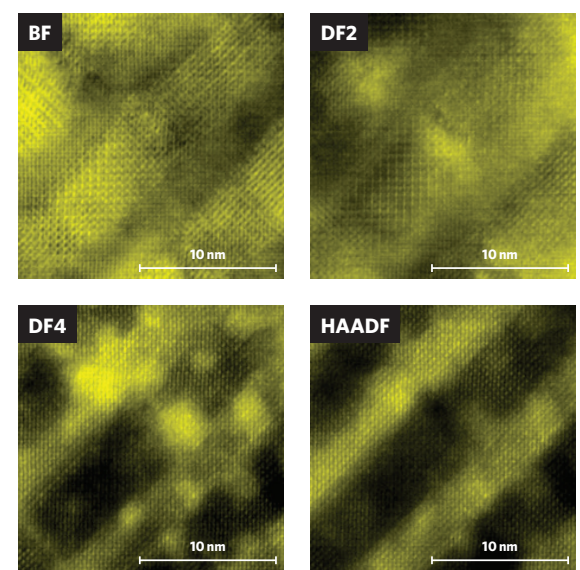

4 channel simultaneous HRSTEM imaging of $\mathrm{SrTiO}_{3}$ using $4 \mathrm{STEM}$ detectors.

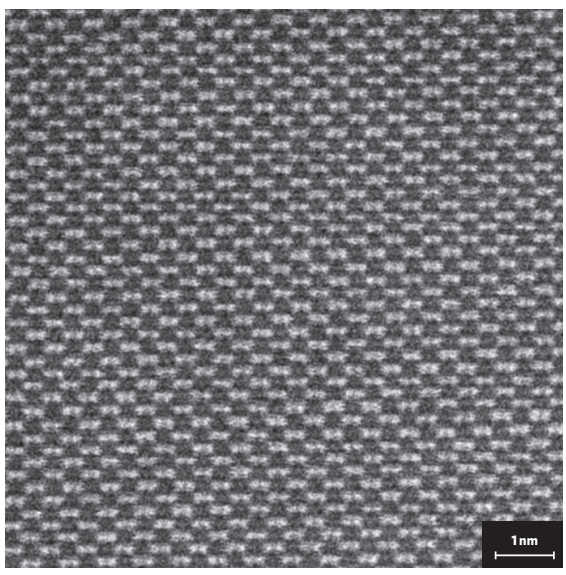

HRSTEM of Si (110) at 200kV.

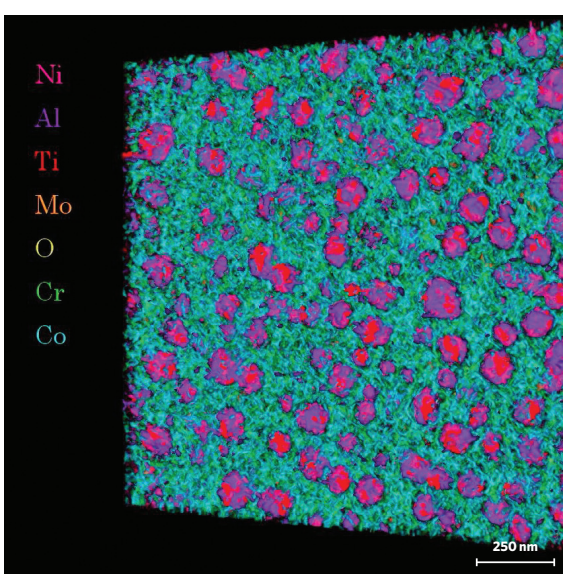

Combined 3D EDS map: Ni, Al, Ti, Mo, Cr, and Co.
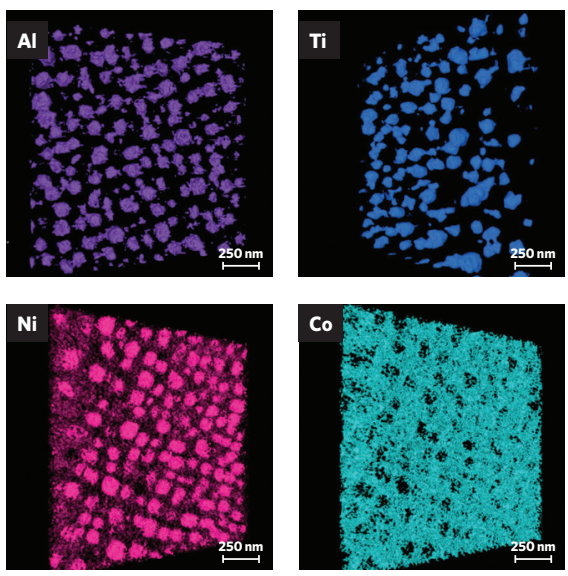

3D EDS maps at different angles.
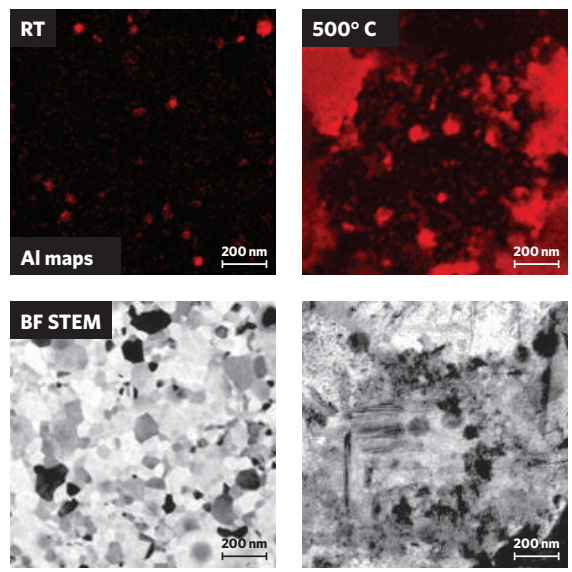

Temperature driven Al aggregation in solar cell. Sample courtesy of Dr. S. Kraschewski, U. Erlangen.

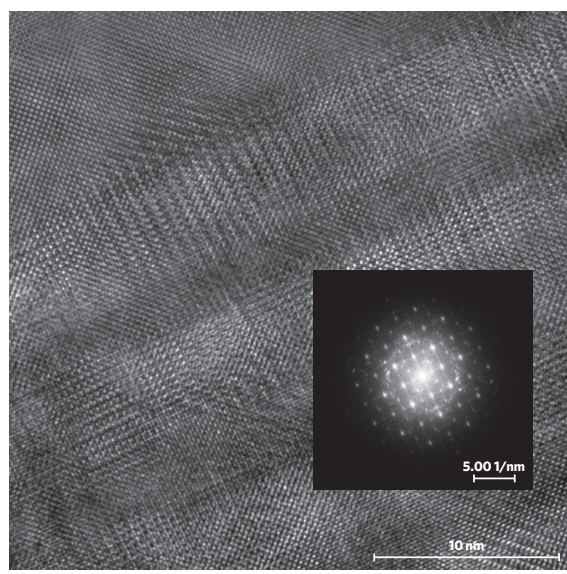

HRTEM image of $\mathrm{SrTiO}_{3}$ with Ceta $16 \mathrm{M}$ camera.

\section{Fast 2D \& 3D Imaging and Chemical Analysis with Talos TEM}

Whether you work with metals, light elements, or nanoparticles-from macro to atomic scales-Talos gives you insight into structure and composition for a complete understanding of material properties.

High speed 2D and 3D EDS analysis: Fast, multichannel, automated EDS acquisition and precise quantification to obtain multidimensional compositional maps.

Fast navigation and imaging: Highest throughput, highest resolution uncorrected S/TEM images - even for beam sensitive and challenging materials.

Space to do more: FEI TEMs have the space to accommodate additional in situ holders for dynamic imaging, diffraction, and tomography applications.

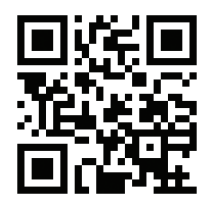

Watch the movie at FEl.com/DiscoverTalos

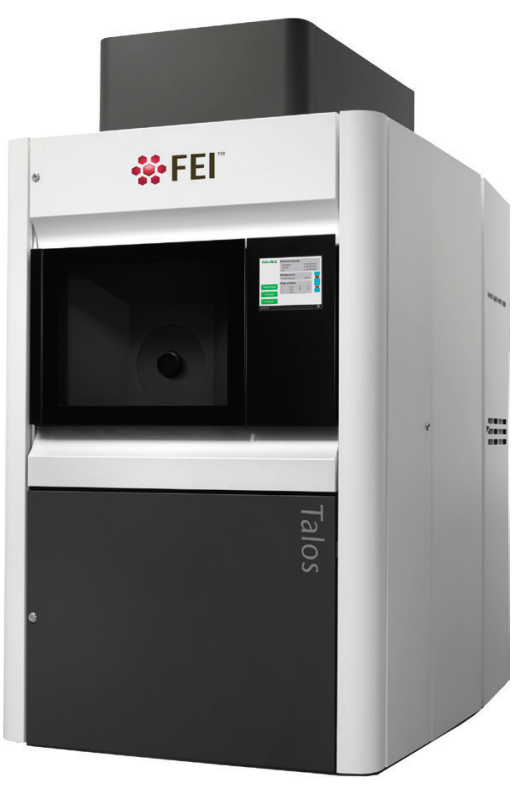

Explore. Discover. Resolve. 


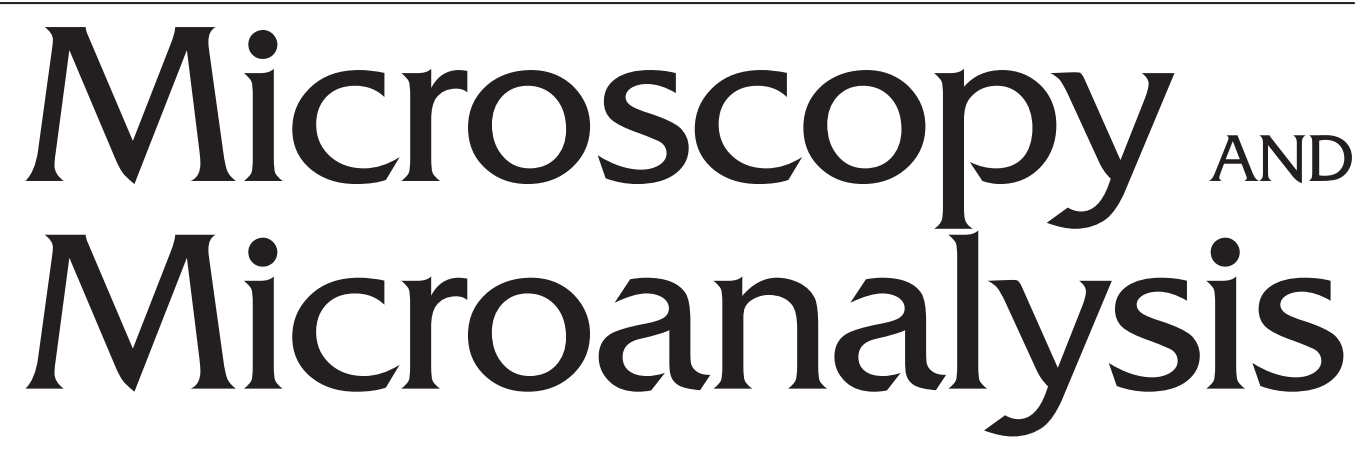

An International Journal for the Biological and Physical Sciences

Volume 21, Number 2

April 2015

\section{Review Article}

A Review of Color Blindness for Microscopists: Guidelines and Tools for

Accommodating and Coping with Color Vision Deficiency

Douglas R. Keene

\section{Equipment Development}

In Situ Heater Design for Nanoscale Synchrotron-Based Full-Field Transmission X-Ray Microscopy

Andrew M. Kiss, William M. Harris, Arata Nakajo, Steve Wang, Joan Vila-Comamala, Alex Deriy, and Wilson K. S. Chiu

Design and Application of a Novel In Situ Nano-Manipulation Stage for Transmission Electron Microscopy

Bon-Woong Koo, Seung-Pyo Hong, Seong-Il Kim, Chan S. Kang, Sang-Sub Han, Kyu H. Oh, and Young-Woon Kim

Development of an Integrated Thermocouple for the Accurate Sample Temperature Measurement During High Temperature Environmental Scanning Electron Microscopy (HT-ESEM) Experiments

Renaud Podor, Damien Pailhon, Johann Ravaux, and Henri-Pierre Brau

\section{Biological Applications}

FtsZ1/FtsZ2 Turnover in Chloroplasts and the Role of ARC3

Carol B. Johnson, Rahamthulla Shaik, Rehab Abdallah, Stanislav Vitha, and Andreas Holzenburg

Collagen Structure Deterioration in the Skin of Patients with Pelvic Organ Prolapse Determined by Atomic Force Microscopy

Svetlana L. Kotova, Peter S. Timashev, Anna E. Guller, Anatoly B. Shekhter, Pavel I. Misurkin, Victor N. Bagratashvili, and Anna B. Solovieva

Analysis of Grayscale Characteristics in Images of Labeled Microtubules from Cultured Cardiac Myocytes

Yongming Dang, Xiaodong Lan, Qiong Zhang, Lingfei Li, and Yuesheng Huang

Comparative Tissue Stainability of Lawsonia inermis (Henna) and Eosin as Counterstains to Hematoxylin in Brain Tissues

Judith N. Alawa, Gbenga O. Gideon, Bamidele Adetiba, and Clement B. Alawa

Flow Cytometry and Electron Microscopy Study of Staphylococcus aureus and Escherichia coli Treated with Mdc-Hly

Xuemei Lu, Xiaobao Jin, and Jiayong Zhu

Effects of Tributyltin Chloride on Developing Mouse Oocytes and Preimplantation Embryos

Xian-Ju Huang, Ming Shen, Lizhong Wang, Fengxiang Yu, Wangjun Wu, and Hong-lin Liu

Structural Heterogenity of Intraluminal Content of The Prostate: A Histochemical and Ultrastructural Study

Paula Badea, Amelia Petrescu, Lucia Moldovan, and Otilia Zarnescu

On the Cover: Phase image of off-axis hologram. For further information please see Zheng et al., pp. 498-509.
Microscopy and Microanalysis website: http://www.journals.cambridge.org/MAM Indexed in Chemical Abstracts, Current Contents, BIOSIS, and MEDLINE (PubMed) 
$\alpha$-Viniferin-Induced Structural and Functional Alterations in Raillietina echinobothrida, a Poultry Tapeworm

Bishnupada Roy and Bikash R. Giri

Analysis of Gill Structure from a Fresh Water Fish (Heteropneustes fossilis) Exposed to Bleached Sulfite Pulp Mill Effluents

Sudip Dey, Utpal Rajguru, Dinesh Chandra Pathak and Umesh C. Goswami

The Incorporation of Nanoparticles into Conventional Glass-lonomer Dental Restorative Cements

Elizabeta Gjorgievska, Gustaaf Van Tendeloo, John W. Nicholson, Nichola J. Coleman, Ian J.

Slipper, and Samantha Booth

XRMA and ToF-SIMS Analysis of Normal and Hypomineralized Enamel

Lisa Melin, Jesper Lundgren, Per Malmberg, Jörgen G. Norén, Fabian Taube, and David H. Cornell

\section{Materials Applications}

A Tool for Local Thickness Determination and Grain Boundary Characterization by CTEM and HRTEM Techniques

Ákos K. Kiss, Edgar F. Rauch, Béla Pécz, János Szivós, and János L. Lábár

Periodic Artifact Reduction in Fourier Transforms of Full Field Atomic Resolution Images

Robert Hovden, Yi Jiang, Huolin L. Xin, and Lena F. Kourkoutis

Robust Focus Measure Operator Using Adaptive Log-Polar Mapping for Three-Dimensional Shape Recovery

Ik-Hyun Lee, Muhammad Tariq Mahmood, and Tae-Sun Choi

Total-Scattering Pair-Distribution Function of Organic Material from Powder Electron Diffraction Data

Tatiana E. Gorelik, Martin U. Schmidt, Ute Kolb, and Simon J. L. Billinge

Characterization of the Thickness and Distribution of Latex Coatings on Polyvinylidene Chloride Beads by Backscattered Electron Imaging

Clifford S. Todd and Douglas E. Beyer

A Model Ni-Al-Mo Superalloy Studied by Ultraviolet Pulsed-Laser-Assisted Local-Electrode Atom-Probe Tomography

Yiyou Tu, Elizaveta Y. Plotnikov and David N. Seidman

Nonequilibrium Microstructures for Ag-Ni Nanowires

Rajesh K. Rai and Chandan Srivastava

Investigation of (Fe,Co)NbB-Based Nanocrystalline Soft Magnetic Alloys by Lorentz Microscopy and Off-Axis Electron Holography

Changlin Zheng, Holm Kirmse, Jianguo Long, David E. Laughlin, Michael E. McHenry, and Wolfgang Neumann

Assessment of In-Depth Degradation of Artificially Aged Triterpenoid Paint Varnishes Using Nonlinear Microscopy Techniques

George Filippidis, Meropi Mari, Lambrini Kelegkouri, Aggelos Philippidis, Aleksandros Selimis, Kristallia Melessanaki, Maria Sygletou, and Costas Fotakis

On the Use of the Unusual Green Pigment Brochantite $\left(\mathrm{Cu}_{4}\left(\mathrm{SO}_{4}\right)(\mathrm{OH})_{6}\right)$ in the 16th-Century Portuguese-Flemish Paintings Attributed to The Master Frei Carlos Workshop

Sara Valadas, Rita V. Freire, Anna Cardoso, José Mirão, Cristina B. Dias, Peter Vandenabeele, and António Candeias

$\mu$-XRF Analysis of Trace Elements in Lapis Lazuli-Forming Minerals for a Provenance Study

Debora Angelici, Alessandro Borghi, Fabrizia Chiarelli, Roberto Cossio, Gianluca Gariani, Alessandro Lo Giudice, Alessandro Re, Giovanni Pratesi, and Gloria Vaggelli

\section{Book Review}

Biomineralization Sourcebook: Characterization of Biominerals and Biomimetic Materials 


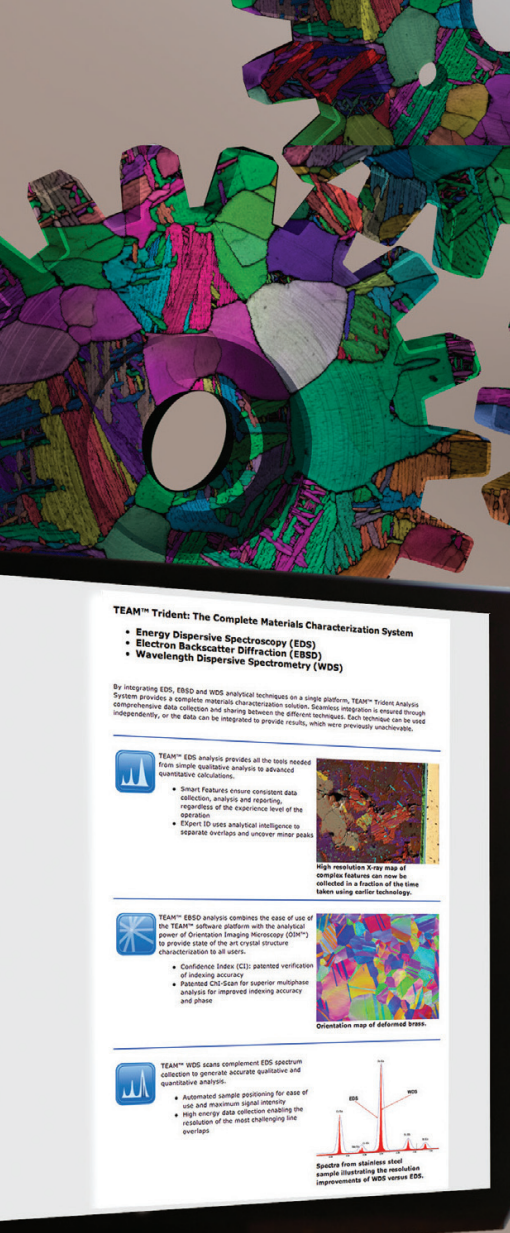

\section{.}
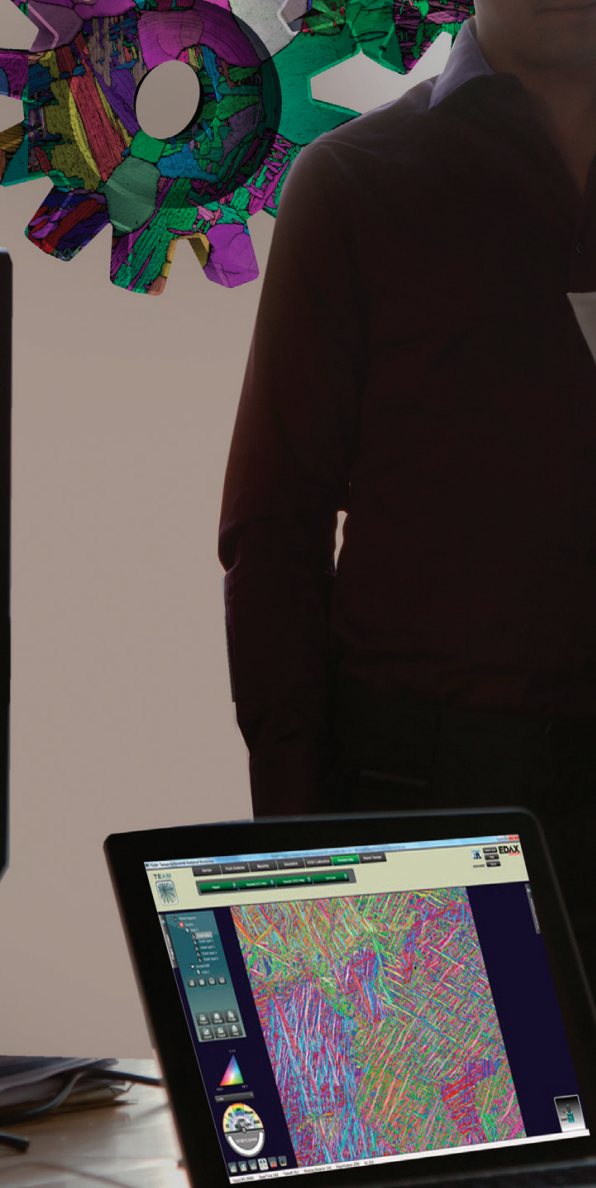

\section{Seamless integration for smart results.}

- EDS, EBSD and WDS seamlessly integrated with a single user interface

- Built-in Smart Features facilitate set-up, guide analysis and automate reporting

- Proven algorithms guarantee quality results

- Streamlined workflows drive productivity with industry-best results in three mouse clicks

\section{Qㅂㅁㅁ Power your next insight with EDAX. edax.com/smart}

\section{NMETEK}

TEAM $^{\mathrm{TM}}$

TEAM $^{\text {m }}$ EDS

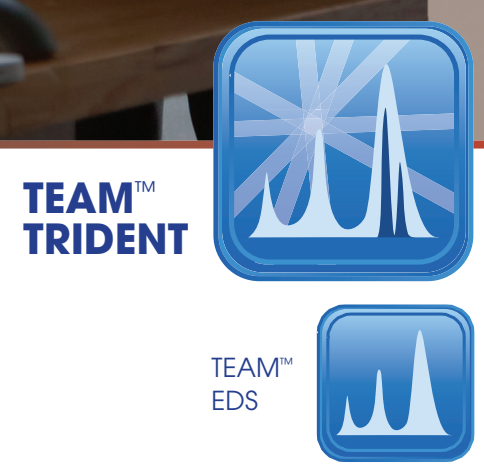

TEAM" EBSD

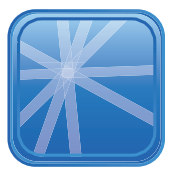

TEAM $^{m}$ WDS
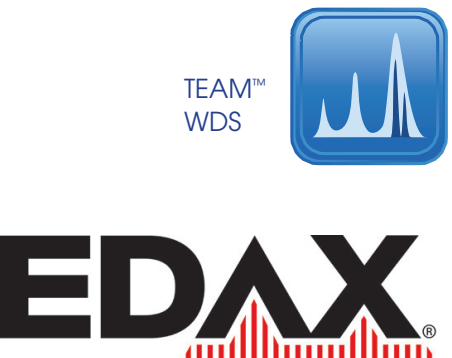
IIIIIIIIIIIIIIIIIIIIIII. Smart Insight 


\section{FOCUS ON ESSENTIAL RESEARCH TOOLS}

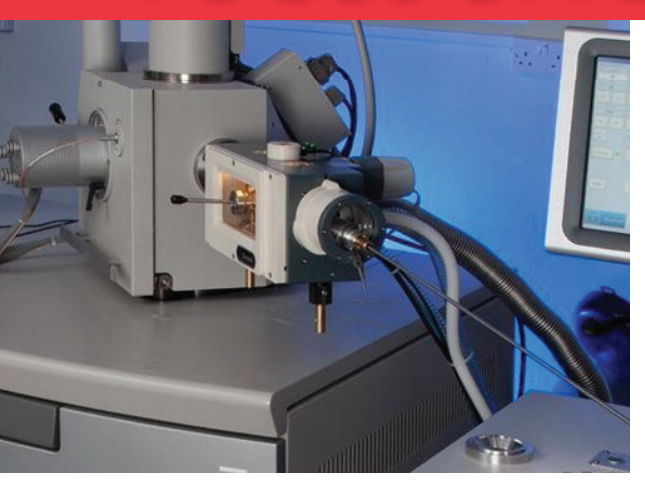

\section{PP3010T Oryo-SEM Preparation System}

The PP3010T is a highly automated, easy-to-use, column-mounted, gas-cooled cryo preparation system suitable for most makes and models of SEM, FE-SEM and FIB/SEM. The PP3010T has all the facilities needed to rapidly freeze, process and transfer specimens. The cryo preparation chamber is turbomolecular pumped and includes tools for cold fracturing, controlled sublimation and specimen coating. The specimen can then be transferred onto a highly stable SEM cold stage for observation. Cold trapping in the cryo preparation chamber and SEM chamber ensures the whole process is frost-free. Specimen process times are typically between five and ten minutes.
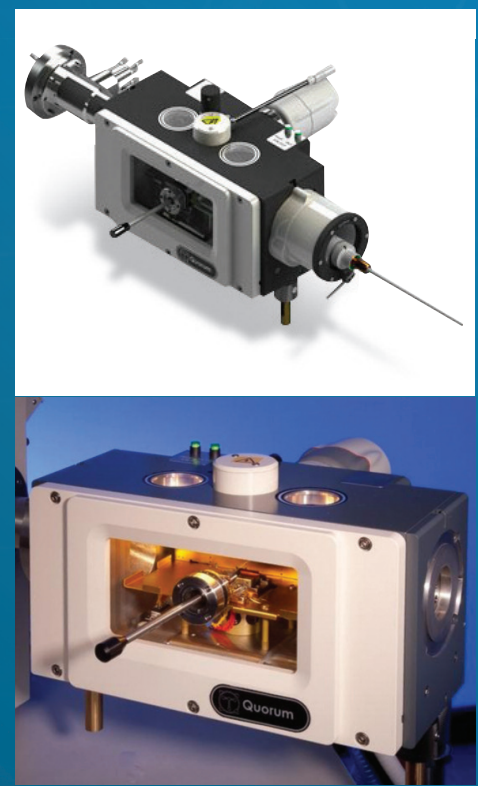

See how it works... Learn how to do it...

We've added video content to our website to help you get to know our latest products even better!

Stop by and see what it's all about.
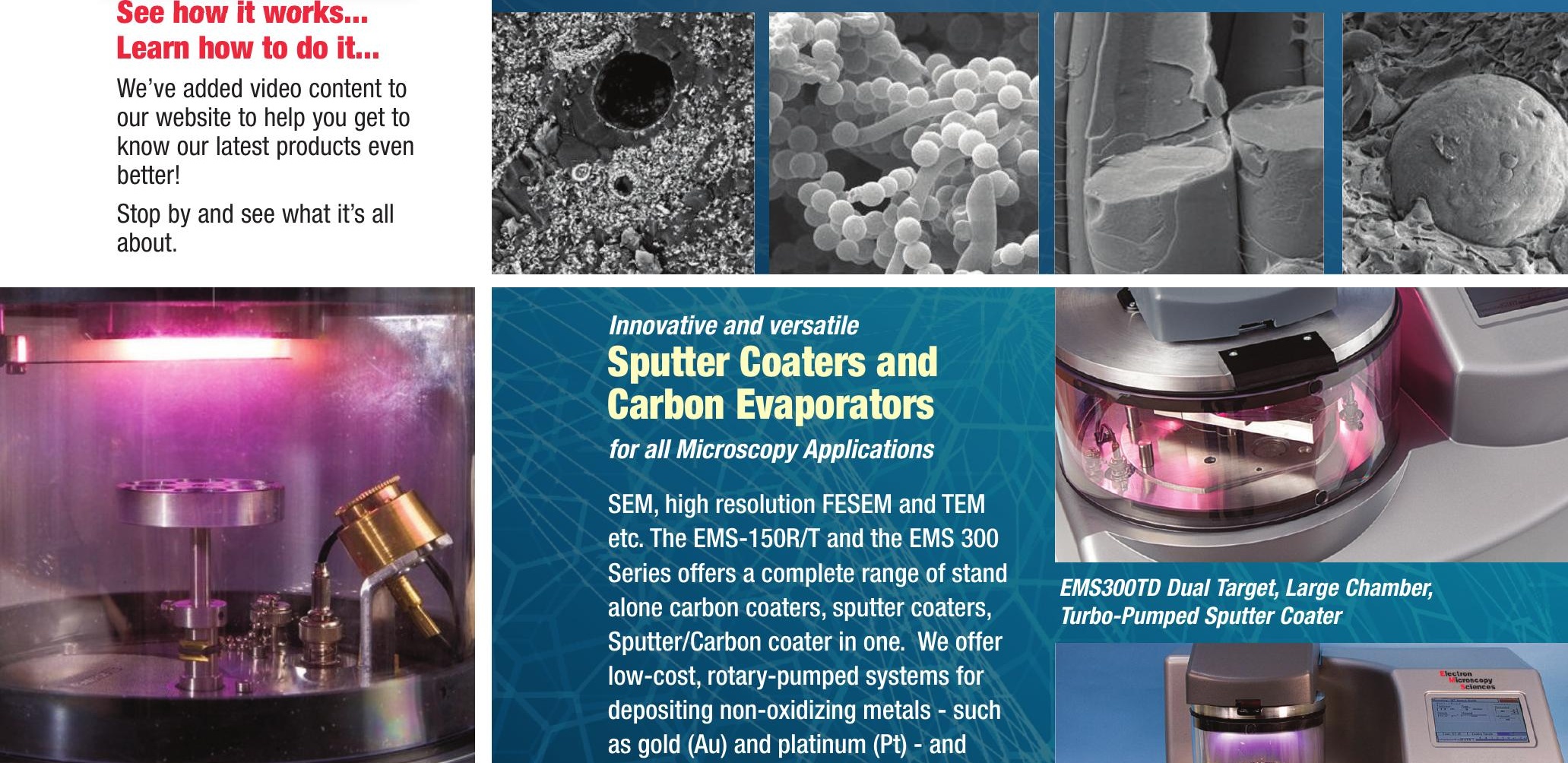

\section{Electron Microscopy Sciences}

P.0. Box $550 \bullet 1560$ Industry Rd. Hatfield, Pa 19440 Tel: (215) 412-8400 Fax: (215) 412-8450 email: sgkcck@aol.com or stacie@ems-secure.com www.emsdiasum.com

\section{Innovative and versatile}

\section{Sputter Coaters and Carbon Evaporators \\ for all Microscopy Applications}

SEM, high resolution FESEM and TEM etc. The EMS-150R/T and the EMS 300 Series offers a complete range of stand alone carbon coaters, sputter coaters, Sputter/Carbon coater in one. We offer low-cost, rotary-pumped systems for depositing non-oxidizing metals - such as gold $(\mathrm{Au})$ and platinum (Pt) - and also turbomolecular-pumped models, suitable for oxidizing and non-oxidizing metals - such as chromium (Cr). Large chamber models are available for specimens up to $8 " / 200 \mathrm{~mm}$ diameter, and all sputter coaters can be fitted with carbon evaporation attachments.

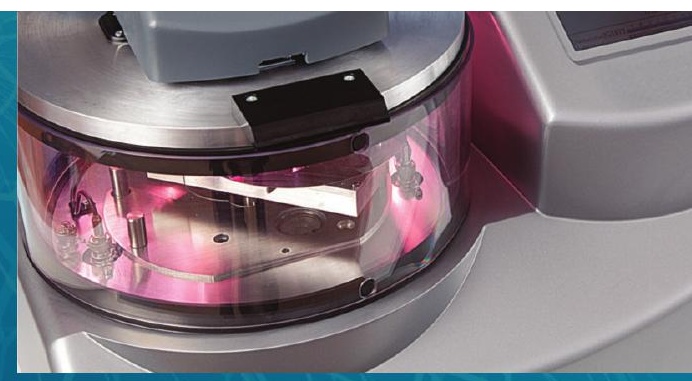

EMS300TD Dual Target, Large Chamber, Turbo-Pumped Sputter Coater

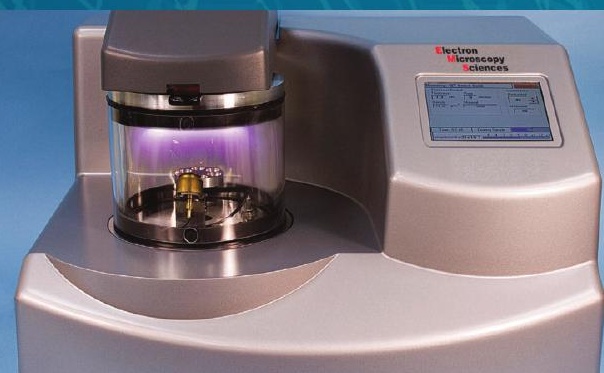

EMS150R Rotary Pumped Carbon and Sputter Coating System
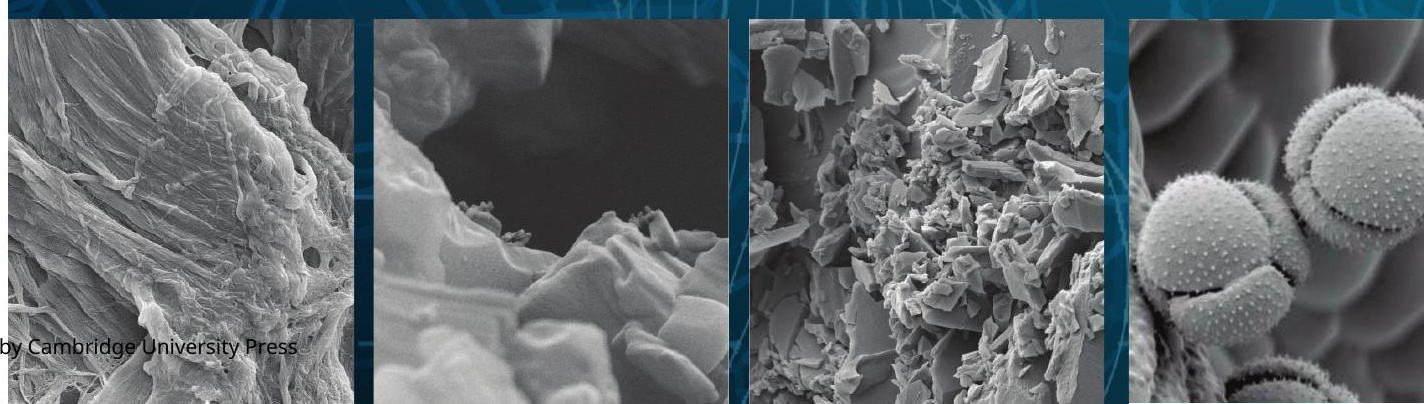


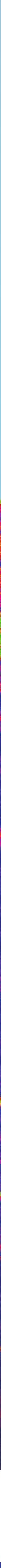

Bacteriophage Epsilon 15, Wah Chiu, Ph.D., Baylor College of Medicine (top image)

Rabbit Retinal Connectome volume; Robert Marc, Ph.D., Marc Lab, Moran Eye Center, Univ. of Utah (middle image)

Neuron, 200nm, tomography; Greg Ning, Ph.D.

Penn State University College of Agricultural Sciences (bottom image)

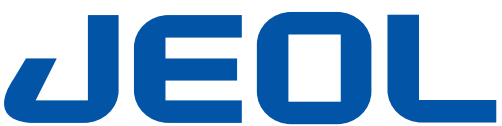

Solutions for Innovation

www.jeolusa.com

salesinfo@jeol.com•978-535-5900

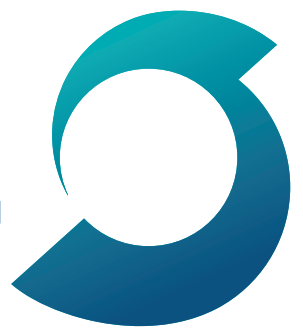

